\title{
Pendampingan Pemenuhan Asupan Nutrisi Saat Pandemi COVID-19 Pada Orang Dewasa Perkotaan
}

\author{
Ginna Megawati, Dewi Marhaeni Diah Herawati \\ Departemen Ilmu Kesehatan Masyarakat, Fakultas Kedokteran, Universitas Padjadjaran \\ E-mail:ginna@unpad.ac.id; E-mail: dewimdh@yahoo.co.id
}

\begin{tabular}{ll}
\hline Article History: & $\begin{array}{l}\text { Abstract: Adults in urban areas were at high risk of } \\
\text { infected by a virus caused by COVID-19. This community }\end{array}$ \\
Received: Feb 22nd 2021 & $\begin{array}{l}\text { service aims were to educate the target group's so they } \\
\text { Revised: March 28 } 28^{\text {th }} 2021\end{array}$ \\
Accepted: May $30^{\text {th }} 2021$ & $\begin{array}{l}\text { recommendations for pandemics time. Using the } \\
\text { service-learning method, virtual education has been }\end{array}$ \\
Keywords: Attitudes, COVID- & $\begin{array}{l}\text { carried out in the form of audio-visual videos was } \\
\text { proven to be able to improve a positive attitude for } \\
\text { 19, Nutrition recommendations, } \\
\text { Urban adults, Virtual education }\end{array}$ \\
\hline
\end{tabular}

\section{Pendahuluan}

Banyak daerah perkotaan di berbagai negara merupakan episentrum pandemi berkaitan dengan karakteristik khasnya yaitu tingginya tingkat polusi udara, padat penduduk, mobilitas tinggi, banyak terdapat pusat kegiatan bersama dan pusat perekonomian. ${ }^{1}$ Indonesia juga menunjukkan kondisi yang sama, berdasarkan data 23 Agustus 2020, kasus positif COVID-19 di perkotaan angkanya lebih tinggi dibandingkan dengan kabupaten, begitu juga dengan kematian akibat COVID-19.2 Data terbaru pada tanggal 23 Mei 2021 masih menunjukkan trend serupa. ${ }^{3}$ Pengamatan berdasarkan kelompok usia menunjukkan kelompok usia dewasa (19 - 59 tahun) merupakan kelompok terbanyak terkena COVID-19 dengan sebaran sebanyak 24,5\% pada usia 1930 tahun, 30\% pada usia 31-45 tahun, dan 23,5\% pada usia 46-59. Selain itu, pasien positif COVID-19 pada usia 46-59 tahun merupakan kelompok dengan risiko kematian tertinggi kedua setelah lansia dengan risiko sekitar 4,25\%. ${ }^{4}$

Kondisi ini menunjukkan bahwa usia dewasa di daerah perkotaan memiliki risiko tinggi terkena COVID-19, sehingga menjadi kelompok sasaran khusus yang perlu mendapatkan perhatian mengingat kelompok usia ini merupakan kelompok usia

\footnotetext{
${ }^{1}$ WHO, Policy Brief: COVID-19 in an Urban World, 2020.

2 Dian Erika Nugraheny, "Tren Kasus Covid-19 di Kota, Desa, dan Perbandingannya dengan Data Dunia," last modified 2020, https://nasional.kompas.com/read/2020/08/27/07105681/tren-kasuscovid-19-di-kota-desa-dan-perbandingannya-dengan-data-dunia?page=all.

3 Satuan Tugas Penanganan COVID-19, “Analisis Data COVID-19 Indonesia Update 23 Mei 2021,"

${ }^{4}$ Ibid.
} 2021. 
produktif sehingga diupayakan agar tidak tertular virus atau jika terkena bisa diminimalkan gejala penyakitnya sehingga tidak menjadi berat atau bahkan berujung kematian.

Pencegahan COVID-19 dapat dilakukan dengan cara mengurangi paparan virus dengan taat melakukan protokol kesehatan 5M (mencuci tangan, memakai masker, menjaga jarak, menghindari kerumunan dan membatasi mobilitas), mendapatkan vaksinasi dan meningkatkan daya tahan tubuh. ${ }^{5}$ Imunitas tubuh perlu dijaga dan ditingkatkan dengan melaksanakan pola hidup sehat seperti cukup tidur, olah raga teratur dan terukur, mengelola stress dengan baik serta intervensi gizi yang tepat. ${ }^{6}$

Kecepatan penularan virus penyebab COVID-19 yang dalam singkat sanggup menyebar di seluruh dunia membuat masyarakat bersikap panik dalam berbagai aspek. Di tengah situasi yang penuh dengan ketidakpastian, jika tidak berhati-hati akan mudah terjebak untuk bersikap tidak rasional. Pesatnya kemajuan teknologi informasi dan penggunaan media sosial tampaknya memfasilitasi melimpahnya informasi dan penyebaranya dengan cepat. Sayangnya seringkali info yang beredar menjadi tidak jelas mana yang akurat atau menyesatkan. ${ }^{7}$ Di Indonesia, informasi yang tidak benar terkait COVID-19 paling banyak ditemukan di media sosial Facebook dan WhatsApp. ${ }^{8}$

Direktur Jenderal WHO, Tedros A. Ghebreyesus, menyatakan bahwa infodemik (informasi menyesatkan mengenai pandemi COVID-19) menyebar lebih cepat dan lebih mudah dibandingkan penyebaran virus itu sendiri. ${ }^{9}$ Hal tersebut menunjukkan bahwa info yang salah mengenai COVID-19 menjadi bahaya tersendiri yang bisa memperparah kondisi pandemi. Informasi akurat dapat menumbuhkan kepercayaan dan rasa aman pada masyarakat sehingga penting untuk menyediakan sumber informasi yang terpercaya. Informasi yang salah bisa menjerumuskan masyarakat pada solusi yang tidak tepat dalam merespon wabah, bahkan dapat memperparah situasi. ${ }^{10}$ Kesalahpahaman tentang berbagai makanan super ("super food") untuk meningkatkan sistem imun justru dapat menyebabkan gangguan imunitas dan menjadi rentan terinfeksi virus. Secara umum semua sistem dalam tubuh kita diciptakan dalam keseimbangan, tidak boleh ada yang terlalu terstimulasi atau kekurangan, begitu pun dengan sistem imun tubuh yang merupakan pertahanan terhadap "serangan"organisma

\footnotetext{
${ }^{5}$ Kementerian Kesehatan RI, "Pedoman Pencegahan Dan Pengendalian Coronavirus Disease (COVID-19)" (2020).

${ }^{6}$ Kementerian Kesehatan RI, “Ayo Bersama Cegah Penularan Virus Corona (COVID-19),” 2020.

${ }^{7}$ Hermin Indah Wahyuni Ambardi et al., Policy Brief: Problem Infodemic Dalam Merespon Pandemi COVID-19, 2020.

8 Oemar Madri Bafadhal dan Anang Dwi Santoso, "Memetakan Pesan Hoaks Berita COVID-19 Di Indonesia Lintas Kategori, Sumber dan Jenis Disinformasi," Bricolage : Jurnal Magister Ilmu Komunikasi 6, no. 2 (2020): 235-249.

${ }^{9}$ John Zarocostas, "How to fight an infodemic," Vol 395, last modified 2020, www.thelancet.com.

${ }^{10}$ Ambardi et al., Policy Brief: Problem Infodemic Dalam Merespon Pandemi COVID-19.
} 
lain termasuk virus. ${ }^{11}$ Panduan Gizi Seimbang Pada Masa Pandemi COVID-19 dari Kementerian Kesehatan RI pada prinsipnya menerangkan pengaturan pola makan berimbang, memperhatikan kebersihan dan keamanan penyiapan serta pengolahan makanan dan membatasi penggunaan garam, gula dan lemak agar tidak berlebihan. ${ }^{12}$

Pemahaman dan pengetahuan yang baik mengenai pola makan dan asupan makan sesuai dengan kebutuhan pada usia dewasa memiliki peran strategis dalam upaya pencegahan kasus COVID-19, memberikan pendampingan serta sumber rujukan yang tepat berupa edukasi terarah pada usia dewasa diharapkan akan merubah sikap menjadi lebih baik untuk diterapkan dalam kehidupan sehari-hari.

Kegiatan pengabdian ini bertujuan untuk memberikan pendidikan pada masyarakat dengan cara pendampingan dan penyuluhan pada orang dewasa di perkotaan, namun karena keterbatasan kondisi saat pandemi, maka dilakukan secara virtual sehingga bisa memenuhi anjuran menghindari kerumunan. Penyampaian secara virtual didukung dengan data bahwa saat inin masyarakat Indonesia sudah terbiasa dengan informasi yang diberikan secara digital, ${ }^{13}$ sehingga penyampaian dalam bentuk digital berupa tayangan audio visual dan secara daring mungkin untuk dilaksanakan.

\section{Metode}

Program pengabdian masyarakat ini mengunakan metode service learning secara daring. Merujuk kegiatan pengabdian yang pernah dilakukan sebelumnya dengan metode ini, 14, 15 kegiatan serupa untuk topik dan sasaran yang berbeda dapat dilakukan. Service learning menggabungkan tujuan akademik berupa tercapainya pengetahuan, pengalaman, dan refleksi dalam mata kuliah lintas bidang dengan keterampilan memecahkan masalah di masyarakat. Hal tersebut dapat dicapai dengan menghubungkan pengetahuan yang didapat di lingkungan pendidikan dengan masalah yang ada dimasyarakat dan berpartisipasi menjadi relawan di komunitas. ${ }^{16}$

Program pengabdian ini dilakukan untuk mendampingi subjek pengabdian agar dapat memenuhi asupan nutrisi saat pandemi Covid-19 sesuai rekomendasi.

${ }^{11}$ Sri Sumarmi, "Kerja Harmoni Zat Gizi dalam Meningkatkan Imunitas Tubuh Terhadap Covid19: Mini Review," Amerta Nutr (2020): 250-256.

12 Kementerian Kesehatan RI, Panduan Gizi Seimbang Pada Masa Pandemi Covid-19, 2020.

${ }^{13}$ Asosiasi Penyelenggara Jasa Internet Indonesia, Laporan survei internet apjii 2019 - 2020, vol. Q2, 2020.

${ }^{14}$ Muh Barid Nizarudin Wajdi et al., "Pendampingan Redesign Pembelajaran Masa Pandemi Covid- 19 bagi Tenaga Pendidik di Lembaga Pendidikan berbasis Pesantren di Jawa Timur," Engagement: Jurnal Pengabdian Kepada Masyarakat 04, no. 01 (2020): 266-277.

${ }^{15}$ Silviana Nur Faizah et al., "Pendampingan Orang Tua Siswa Melalui Penyusunan Media Alat Hitung Manual ( ALHIMA ) dalam Mendampingi Anak Belajar dari Rumah Selama Masa Pandemi Covid19," Engagement: Jurnal Pengabdian Kepada Masyarakat 04, no. 02 (2020): 327-342.

${ }^{16}$ Endah Setyowati dan Alviani Permata, "Service Learning : Mengintegrasikan Tujuan Akademik Dan Pendidikan Karakter Peserta Didik Melalui Pengabdian Kepada Masyarakat" 1, no. 2 (2018): 143152. 
Diharapkan subjek pengabdian akan mengetahui kebiasaan makan, jenis makanan dan frekuensi makan yang tepat serta menerapkan pola makan gizi seimbang sebagai salah satu upaya pencegahan terkena Covid-19. Pendampingan dilakukan dalam 3 tahap, yakni tahap persiapan, tahap melayani, dan tahap refleksi. ${ }^{17}$

Subjek pengabdian adalah masyarakat usia dewasa usia (19-59 tahun), tinggal di daerah perkotaan dan bersedia mengikuti rangkaian pendampingan selama 2 minggu. Subjek direkrut dengan cara menyebarkan formulir melalui google form selama satu minggu, dicari sesuai kriteria inklusi tersebut.

Tahap persiapan dilakukan dengan memetaan permasalahan yang dihadapi subjek pengabdian dengan cara mengumpulkan dan menggali permasalahan atau isu mengenai asupan nutrisi selama pandemi COVID-19. Kemudian tim PKM melakukan analisis kebutuhan dan dilakukan persiapan pembuatan materi edukasi sesuai kebutuhan. Tim PKM melakukan diskusi grup terarah (focus grup discussion) dengan narasumber ahli dari Divisi Ilmu Gizi Medik Fakultas Kedokteran Universitas Padjadjaran untuk merumuskan materi edukasi, pesan yang tepat dan cara berkomunikasi dalam bentuk audio visual.

Tahap pelayanan pendampingan dilakukan secara daring. Kegiatan pendampingan terdiri dari (1) sosialisasi kegiatan, tim menyampaikan inform consent pada peserta yang terdaftar dan bersedia mengikuti seluruh rangkaian kegiatan. Subjek pengabdian diminta untuk bergabung dalam kelompok WhatsApp (WhatsApp Grup/WAG). Diberikan arahan mengenai bagaimana cara penyuluhan akan dilakukan. Video edukasi diunggah ke Youtube, tautannya disampaikan pada subjek pengabdian secara personal ataupun dalam WAG mulai tanggal 6 Juli 2020. Pemberian tautan agar peserta tidak perlu mengunduh file video dalam gawai-nya.

Tahap selanjutnya adalah (2) tahap melayani, Tim PKM meminta subjek pengabdian untuk mengisi angket pre-kegiatan yang diberikan melalui googleform. Angket tersebut terdiri dari dua bagian, pada bagian pertama berisi data umum dan bagian kedua terdiri dari 10 pertanyaan yang dirancang dengan menggunakan skala likert dengan 5 pilihan sikap yaitu SS: Sangat Setuju, S: Setuju, KS: Kurang Setuju, TS: Tidak Setuju dan STS: SangatTidak Setuju.

Setelah semua subjek pengabdian mengisi angket pra-kegiatan, tautan video edukasi diberikan. Pendampingan dilakukan dengan cara mengulang info dalam waktu 2 minggu serta peserta diminta untuk memenuhi asupan nutrisi sesuai dengan isi dari edukasi tersebut, kesulitan dan pertanyaan yang timbul dibahas dalam WAG. Setelah 2 minggu kelompok sasaran kembali diminta untuk mengisi angket. Pengisian angket pre dan post edukasi bertujuan untuk mengetahui perubahan sikap responden terhadap

17 Wajdi et al., "Pendampingan Redesign Pembelajaran Masa Pandemi Covid- 19 bagi Tenaga Pendidik di Lembaga Pendidikan berbasis Pesantren di Jawa Timur." 
pemenuhan nutrisi selama masa pandemi COVID-19.

\section{Hasil Dinamika Proses Pendampingan}

\section{Tahap persiapan}

Pada tahap persiapan diketahui bahwa isu mengenai asupan nutrisi saat pandemi COVID-19 pada usia dewasa di perkotaan berkaitan dengan kesulitan memahami rekomendasi pengaturan gizi seimbang, sehingga informasi yang bersifat lebih aplikatif untuk dilaksanakan sehari-hari akan lebih baik, begitu juga dengan isu mengenai pemberian suplementasi vitamin, mineral dan zat gizi lainnya saat pandemi COVID-19. Hal tersebut menjadi topik bahasan yang dibahas dengan narasumber ahli sebagai bahan pembuatan materi edukasi serta diskusi teknis mengenai kualitas audio visual yang dihasilkan.

\section{Tahap Pelaksanaan}

Subjek pengabdian yang awalnya bersedia ikut terlibat dalam kegiatan ini ada 120 orang, namun hanya 88 orang yang akhirnya berhasil mengikuti seluruh rangkaian kegiatan secara lengkap (pre, post tes serta menonton video edukasi). Angka terbesar drop out terjadi pada kelompok umur 19-45 tahun. Sebagian besar merasa tidak ada waktu untuk mengikuti proses secara lengkap, dan keberatan untuk mengulang info yang sudah pernah didapatkan.

Edukasi gizi dibuat secara umum mengenai gizi seimbang dan penggunaan zat gizi yang dapat membantu sistem imunitas tubuh. Pembuatan materi edukasi yang lebih terarah akan sangat membantu masyarakat untuk mengaplikasikan rekomendasi tersebut dalam kehidupan sehari-hari.

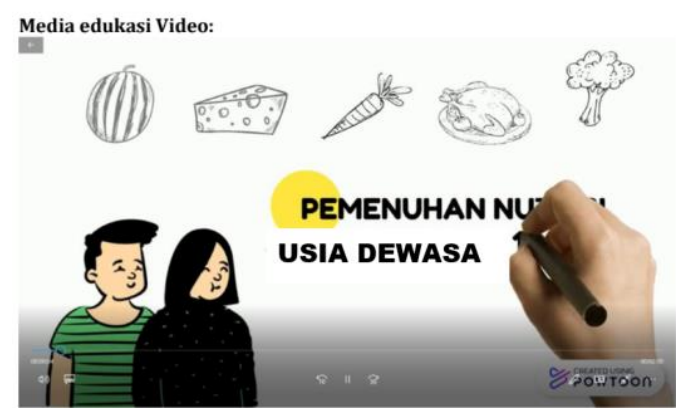

Gambar 1. Video edukasi

Tahap ketiga, Evaluasi. Dalam tahap ini tim melakukan evaluasi dari proses edukasi virtual yang sudah dilakukan pada kelompok sasaran. 


\section{Hasil Edukasi}

Gambaran responden yang mengikuti kegiatan ini tampak pada tabel 1.

Tabel. 1 Karakteristik Peserta Edukasi

\begin{tabular}{|c|c|c|c|c|}
\hline No & Variabel & & frekuensi & $\%$ \\
\hline \multirow{2}{*}{1} & \multirow{2}{*}{ Jenis Kelamin } & Laki-laki & 32 & 36 \\
\hline & & Perempuan & 56 & 64 \\
\hline \multirow{5}{*}{2} & \multirow{5}{*}{ Usia } & $19-25$ & 9 & 10 \\
\hline & & $26-35$ & 19 & 21 \\
\hline & & $36-45$ & 5 & 6 \\
\hline & & $46-55$ & 27 & 31 \\
\hline & & $55-59$ & 28 & 32 \\
\hline \multirow{4}{*}{3} & \multirow{4}{*}{ Tingkat pendidikan } & SD & 4 & 4 \\
\hline & & SMP & 6 & 7 \\
\hline & & SMU & 23 & 26 \\
\hline & & Universitas & 55 & 63 \\
\hline \multirow{7}{*}{4} & \multirow{7}{*}{ Pekerjaan } & Wiraswasta & 13 & 15 \\
\hline & & Pegawai Swasta & 22 & 25 \\
\hline & & PNS/TNI/POLRI & 16 & 19 \\
\hline & & Guru/Dosen & 7 & 8 \\
\hline & & Mahasiswa & 4 & 4 \\
\hline & & Tidak bekerja & 18 & 21 \\
\hline & & Lain-lain & 8 & 8 \\
\hline \multirow{8}{*}{5} & \multirow{8}{*}{$\begin{array}{c}\text { Provinsi Tempat } \\
\text { Tinggal }\end{array}$} & Jawa Barat & 68 & 78 \\
\hline & & DKI Jakarta & 4 & 4 \\
\hline & & Sumatera Utara & 2 & 2 \\
\hline & & Sumatera Barat & 1 & 1 \\
\hline & & Aceh & 1 & 1 \\
\hline & & Bali & 1 & 1 \\
\hline & & Banten & 6 & 7 \\
\hline & & DIY & 5 & 6 \\
\hline
\end{tabular}

Setelah mendapatkan edukasi selama 2 minggu terlihat perubahan sikap kelompok sasaran terhadap pernyataan yang berhubungan dengan kebiasaan pola makan dengan 
gizi seimbang dan beragam, seperti yang tampak pada tabel 2 .

Tabel. 2 Perubahan Sikap kelompok sasaran pre- dan post edukasi

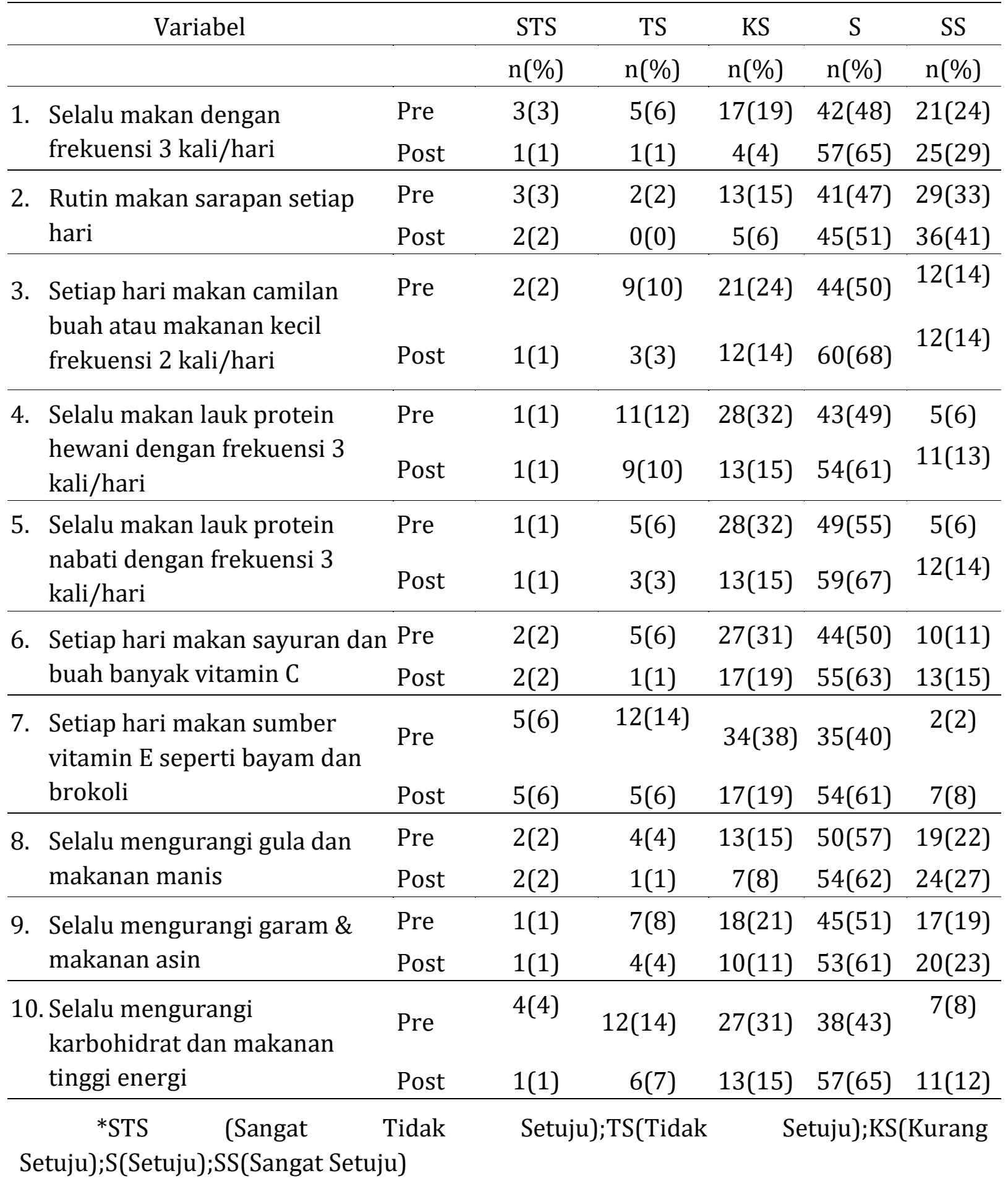

Hasil dari survei pre-dan post- edukasi menunjukkan adanya perubahan 
sikap responden terhadap pola makan, jenis, jumlah dan frekuensi makan. Sebelum diberi edukasi sebagian besar responden sudah menunjukkan sikap positif (Setuju dan Sangat Setuju) terhadap 10 jenis pernyataan yang disampaikan kecuali untuk pernyataan nomor 4 tentang asupan lauk protein hewani (55\%) dan asupan sumber vitamin E (42\%).

\section{Diskusi}

Tingkat drop-out pada kegiatan pengabdian ini adalah sekitar 26,67\%. Alasan yang disampaikan adalah merasa tidak ada waktu untuk mengikuti proses secara lengkap, dan keberatan untuk mengulang info yang sudah pernah didapatkan. Alasan tersebut menunjukkan pemberian informasi berulang dengan format yang sama tampaknya tidak menarik minat dan perhatian subjek pengabdian. Pengulangan informasi dalam waktu dua minggu dimaksudkan agar subjek pengabdian memiliki cukup waktu untuk memahami dan melakukan perubahan perilaku terhadap pernyataan atau rekomendasi yang diberikan.

Sebagian besar subjek pengabdian menyelesaikan pendidikan di Universitas, sehingga sudah memiliki pengetahuan dasar mengenai pola makan bergizi dan seimbang. Subjek pengabdian menunjukkan sikap positif (menyatakan setuju dan sangat setuju) terhadap seluruh pernyataan yang disampaikan, tetapi untuk beberapa pernyataan tertentu persentase-nya kurang dari $80 \%$ yaitu untuk pernyataan terkait pemenuhan protein hewani (pernyataan nomor 4), pemenuhan asupan buah dan sayur (pernyataan nomor 3, 6 dan 7) serta mengurangi makanan sumber karbohidrat dan makanan tinggi energi (pernyataan nomor 10).

Hasil survei pada subjek pengabdian menunjukkan hanya sekitar 55\% yang bersikap positif terhadap pernyataan pemenuhan sumber protein (lauk) hewani (pernyataan nomor 4), setelah edukasi meningkat menjadi 74\%. Protein hewani diperlukan salah satunya untuk meningkatkan imunitas tubuh, dalam kondisi normal diperlukan jumlah asupan sekitar $65 \mathrm{gr} / \mathrm{hari}$ untuk dewasa laki-laki, wanita dewasa 60g/hari, ${ }^{18}$ pada masa pandemi COVID-19 ini rekomendasinya bahkan bisa ditingkatkan menjadi 75-100 gr/hari. Jika sebelumnya disarankan mengkonsumsi 3 porsi protein hewani/hari, maka sebagai pencegahan COVID-19 ditambahkan 1 porsi protein hewani menjadi 4 porsi protein hewani/hari. ${ }^{19}$

Kondisi ini sebenarnya bukan hal baru karena konsumsi protein hewani di Indonesia memang masih sangat rendah jika dibandingkan negara lain bahkan dalam

\footnotetext{
${ }^{18}$ Menteri Kesehatan RI, "Peraturan Menteri Kesehatan Republik Indonesia No. 28 tahun 2019 tentang Angka Kecukupan Gizi Yang dianjurkan Untuk Masyarakat Indonesia," 2019.

${ }_{19}$ Perhimpunan Dokter Spesialis Gizi Klinik Indonesia, Panduan Praktis Penatalaksanaan Nutrisi COVID-19, 1 ed., 2020.
} 
lingkup negara ASEAN. Menurut data dari Food and Agriculture Organization (FAO) pada tahun 2017 tingkat konsumsi protein hewani dari total konsumsi protein di Indonesia hanya sekitar 8\%, jauh dibawah Malaysia (30\%), Thailand (24\%) dan Filipina (21\%). Kondisi ini masih terus berlangsung, berdasarkan data Survei Sosial Ekonomi Nasional (SUSENAS) tahun 2019 dari Badan Pusat Statistik (BPS) diketahui bahwa konsumsi protein hewani memang lebih kecil dari konsumsi protein nabati (padipadian). Konsumsi protein hewani hanya 25.32\% dari total konsumsi protein sedangkan protein dari padi-padian mencapai 30.43\%. Penduduk Indonesia mengeluarkan sekitar 49,21\% dari pengeluaran bulanannya untuk makanan, namun pengeluaran terbesar untuk makanan tetap untuk komoditas padi-padian serta makanan dan minuman jadi. ${ }^{20}$

Penelitian mengenai keragaan konsumsi pangan hewani berdasarkan pendapatan menunjukkan bahwa semakin tinggi pendapatan rumah tangga semakin besar tingkat konsumsi protein hewani. Protein hewani yang dikonsumsi adalah daging dan telur ayam ras, daging sapi serta ikan laut. Kelompok rumah tangga berpendapatan tinggi lebih memperhatikan aspek kualitas, kesehatan dan keamanan pangan dalam memilih makanan. Sedangkan untuk kelompok rumah tangga pendapat rendah kuantitas makanan lebih penting daripada kualitasnya. ${ }^{21}$

Kondisi pandemi COVID-19 diprediksi akan mengganggu ketahanan pangan nasional karena menurunnya produksi pertanian akibat pembatasan pergerakan orang atau tenaga kerja dan penurunan daya beli masyarakat. ${ }^{22}$ Kondisi ini perlu mendapatkan perhatian karena kelompok rumah tangga dengan pendapatan rendah akan semakin sulit memenuhi kebutuhan asupan protein, dampaknya tentu saja tidak hanya berkaitan dengan upaya meningkatkan daya tahan tubuh saja tetapi juga dapat mempengaruhi status gizi jangka panjang terutama bagi generasi muda. ${ }^{23}$

Hasil lainnya dari survei ini yang menarik perhatian adalah sikap subjek penelitian terhadap pernyataan mengenai asupan sumber vitamin E dari sayuran. Hanya sekitar $42 \%$ yang bersikap positif terhadap pernyataan itu sebelum diberikan edukasi. Setelah diberikan edukasi, terjadi peningkatan presentase peserta edukasi yang bersikap positif menjadi $62 \%$, tetapi secara keseluruhan responden yang bersikap positif terhadap pemenuhan asupan sayur dan buah masih dibawah 80\%. Beberapa pernyataan lainnya yang berkaitan dengan asupan buah dan sayur tampak pada pernyataan nomor 3 (camilan buah) hanya 72\% yang bersikap positif dan pernyataan

\footnotetext{
${ }^{20}$ Kementerian Pertanian RI, "Kebijakan Pemerintah dalam Mendukung Terwujudnya Kemandirian Protein Hewani," diakses Februari 1, 2021, https://www.agropustaka.id/presentasi/unduh.

${ }^{21}$ Mewa Ariani et al., "Keragaan Konsumsi Pangan Hewani Berdasarkan Wilayah dan Pendapatan Di Tingkat Rumah Tangga," Analisis Kebijakan Pertanian 16, no. 2 (2018): 147-163.

22 Kementerian Pertanian RI, "Kebijakan Pemerintah dalam Mendukung Terwujudnya Kemandirian Protein Hewani."

${ }^{23}$ Sumarmi, "Kerja Harmoni Zat Gizi dalam Meningkatkan Imunitas Tubuh Terhadap Covid-19: Mini Review."
} 
nomor 6 (sumber vitamin C) sebanyak 78\%.

Kondisi ini sebenarnya sejalan dengan gambaran SUSENAS 2019 bahwa jumlah konsumsi sayur dan buah kita masih jauh dari ambang batas yang ditetapkan oleh WHO dan Kemenkes, yang merekomendasikan konsumsi sayur dan buah per orang per hari adalah 400 gram, konsumsi sayur diharapkan lebih banyak dari buah, yaitu 250 gram sayuran dan 150 gram buah-buahan. Sayur dan buah merupakan bahan makanan sumber mineral dan vitamin, berkaitan dengan upaya pencegahan COVID-19 tentunya menjadi sumber yang sangat baik sebagai antioksidan yang berperan membantu daya tahan tubuh, karena itu direkomendasikan untuk menambah jumlah asupan sayur dan buah, lebih baik lagi jiga bisa beraneka ragam warna sehingga memperkaya zat gizi yang terkandung didalamnya. ${ }^{24}$

Penelitian di 10 puskesmas di Yogyakarta dan Sleman pada dokter dan pasien menunjukkan bahwa pasien lebih memilih lauk berupa gorengan dibandingkan sayur dan buah dengan alasan tempe, bakwan dan aneka bahan lainnya yang digoreng lebih murah. Pada penelitian tersebut pesan mengenai porsi buah dan sayur yang harus dikonsumsi menjadi sorotan, masih terdapat persepsi yang berbeda mengenai berapa porsi seharusnya buah dan sayur dikonsumsi serta kaitannya dengan upaya pencegahan penyakit tidak menular. Disarankan agar intervensi promosi kesehatan bersifat menyeluruh serta pesan yang disampaikan perlu menarik, detail tapi mudah difahami serta dilakukan berulang. ${ }^{25}$

Subjek pengabdian yang bersikap positif terhadap penyataan mengurangi karbohidrat dan makanan/minuman tinggi energi masih cukup rendah, hanya sekitar 51\% sebelum edukasi dan $77 \%$ setelah edukasi. Pembatasan asupan karbohidrat dan makanan tinggi energi berkaitan dengan kejadian obesitas dan penyakit komorbidnya antara lain diabetes melitus dan penyakit jantung koroner. ${ }^{26}$ Rekomendasi asupan karbohidrat harian adalah sekitar 45-65\% dari asupan energi harian, disarankan untuk memilih sumber karbohidrat kompleks yang memberikan efek lebih lama kenyang karena lebih sulit dicerna dibandingkan karbohidrat simpleks yang banyak ditemukan dalam makanan jajanan yang tinggi tepung, tinggi gula serta minuman tinggi energi. ${ }^{27}$

Diketahui bahwa konsumsi minuman berpemanis di Indonesia cukup tinggi sekitar 20,23 liter/orang/tahun. Di Asia tenggara, Indonesia merupakan negara ke-3 terbanyak konsumsi minuman berpemanis. ${ }^{28}$ Penelitian mengenai determinan sosial

${ }^{24}$ Kementerian Kesehatan RI, Panduan Gizi Seimbang Pada Masa Pandemi Covid-19.

25 Yusuf IU Prabandari YS, Bintoro BS, "Pertanyaan dan nasihat dokter untuk konsumsi sayur dan buah:penelitian potong lintang pada 10 puskesmas di Yogyakarta dan Sleman," Jurnal Gizi Klinik Indonesia 10, no. 2 (2013).

${ }^{26}$ Forouhi NG O'Connor L, Imamura F, Brage S, Griffn SJ, Wareham NJ, "Intakes and sources of dietary sugars and their association with metabolic and infammatory markers," Clin Nutr 37 (2018): 1313-1322.

27 World Health Organization, Guideline: Sugars Intake for Adults and Children, 2015.

${ }^{28}$ Fakultas Kedokteran Universitas Gadjah Mada, "Konsumen Minuman Berpemanis Tertinggi Ke- 
ekonomi konsumsi minuman berpemanis di Indonesia, diketahui bahwa akses internet serta penggunaan sosial media berpengaruh terhadap tingkat asupan minuman berpemanis. ${ }^{29}$ WHO menyarankan orang dewasa dan anak-anak untuk mengurangi asupan gula hingga kurang dari 10\% dari total asupan energi dan dilanjutkan hingga kurang dari 5\% dari total asupan energi .30,31

Hal ini perlu mendapat perhatian karena berpotensi menjadi penyebab timbulnya penyakit terkait obesitas dikemudian hari. Berdasarkan riset kesehatan dasar (RISKESDAS) jumlah kejadian obesitas di Indonesia terus meningkat dari 15,4\% pada tahun 2013 menjadi 21,8\% pada tahun 2018. ${ }^{32}$ Terkait COVID-19, pasien dengan komorbid (penyakit penyerta) seperti diabetes melitus dan obesitas memiliki risiko tinggi untuk mengalami perburukan kondisi klinis. ${ }^{33,34}$

Kementerian kesehatan merekomendasikan pola makan yang sehat dalam bentuk kampanye ISI PIRINGKU yang merupakan acuan sajian setiap kali kita makan, dalam piring makan harus berisi sumber karbohidrat (makanan pokok) diisi sekitar $1 / 3$ piring, sayuran sebanyak $1 / 3$ piring sisanya diisi oleh sumber protein hewani (lauk hewani), protein nabati (lauk nabati), dan buah. Selain itu juga memperhatikan kecukupan air minum (8-12 gelas/hari) dan membatasi asupan garam, gula dan lemak. Kampanye ini menggantikan kampanye gizi "4 sehat 5 sempurna". Proporsi makanan juga diatur dalam ISI PIRINGKU sehingga dengan mengikuti anjuran tersebut akan menjaga jumlah dan jenis makanan secara seimbang dan tidak berlebihan. ${ }^{35}$

Saat ini internet berkembang dengan sangat cepat, pandemi COVID-19 bahkan mengakselerasi pemenuhan kebutuhan melalui internet. Hampir semua kebutuhan individu dapat terpenuhi melalui internet. Laporan International Telecommunication Union (ITU) pada tahun 2018 terdapat sekitar 3,9 miliar orang pengguna internet di dunia, jumlah ini melebihi setengah populasi di dunia. Di Indonesia perkembangan pengguna internet pun naik dengan pesat, menunjukkan kenaikan sebesar 27,9 juta

3 di Asia Tenggara," diakses Januari 20, 2021, https://fk.ugm.ac.id/indonesia-konsumen-minumanberpemanis-tertinggi-ke-3-di-asia-tenggara/Indonesia.

${ }^{29}$ Widi Astutty Casimira Daeli dan Atik Nurwahyuni, "Determinan Sosial Ekonomi Konsumsi Minuman Berpemanis di Indonesia: Analisis Data Susenas 2017," Jurnal Ekonomi Kesehatan Indonesia 4, no. 1 (2019).

${ }^{30}$ World Health Organization, Guideline: Sugars Intake for Adults and Children.

${ }^{31} \mathrm{H}$ Warshaw dan Steven V. Eldeman, "Practical Strategies to Help Reduce Added Sugars Consumption to Support Glycemic and Weight Management Goals," American Diabetes Association 39, no. 1 (2020).

32 Kementerian Kesehatan RI,"Riset Kesehatan Dasar,"(2018)

${ }^{33} \mathrm{Hu} \mathrm{FB}$, "Resolved: there is suffcient scientifc evidence that decreasing sugar-sweetened beverage consumption will reduce the prevalence of obesity and obesity-related diseases," Obes $\operatorname{Rev}(2013) ; 14: 606-619$

34 Sattar N, McInnes IB, and McMurray JV,"Obesity a Risk Factor for Severe COVID-19 Infection: Multiple Potential Mechanisms" Circulation. (May 2020)

35 Menteri Kesehatan RI, Permenkes No. 14 Tahun 2014 tentang Pedoman Gizi Seimbang, 2014. 
pengguna sehingga pengguna internet di Indonesia sudah mencapai 171,1 juta orang. ${ }^{36}$

Kondisi tersebut memungkinkan dikembangkannya metode edukasi kesehatan audio visual yang berbasis internet dengan memanfaatkan media sosial. Selain sebagai media hiburan, saat ini media sosial juga dijadikan sarana mencari dan berbagi berbagai informasi termasuk masalah kesehatan dan COVID-19. Keuntungan terbesar dari pemanfaatan medial sosial sebagai wahana edukasi adalah luasnya aksesibilitas dan efisiensi biaya. Media edukasi virtual dapat dikemas menarik sehingga memudahkan pemahaman, hal penting lainnya yang harus diperhatikan adalah konten yang terkandung dalam media edukasi kesehatan harus merujuk dari sumber yang bisa dipercaya. 37 Berdasarkan hasil dari pengabdian masyarakat ini, edukasi virtual bisa dijadikan pilihan untuk melakukan edukasi, selain karena masyarakat saat ini sudah terbiasa dengan informasi digital, pelaksanaan edukasinya pun memberikan banyak nilai lebih seperti murah, bisa menjangkau populasi yang luas dibandingkan edukasi tatap muka langsung serta memenuhi saran untuk melakukan protokol kesehatan pencegahan COVID-19 berupa menghindari kerumunan dan menjaga jarak.

\section{Simpulan}

Kegiatan pengabdian kepada masyarakat berupa pendampingan pemenuhan asupan nutrisi saat pandemi COVID-19 pada orang dewasa di perkotaan dapat menjadi salah satu solusi pada kondisi pandemi. Menggunakan metode service learning secara daring, subjek pengabdian memiliki pengetahuan dan perubahan sikap mengenai pemenuhan asupan nutrisi yang diperlukan di masa pandemi COVID-19. Setelah pendampingan, subjek pengabdian dapat mengaplikasikan pengaturan nutrisi dengan gizi seimbang sesuai rekomendasi dalam kehidupan sehari-hari. Sebagai saran dari segi konten, sebaiknya ada perhatian khusus untuk materi edukasi mengenai bagiamana cara memenuhi kebutuhan protein(lauk) hewani, sayur dan buah serta pembatasan makanan/minuman tinggi energi. Saran untuk penyajian, materi edukasi berupa audio visual jika akan disampaikan berulang-ulang, sebaiknya dibuat lebih dari satu jenis bervariasi cara penyampainan meskipun isi pesannya sama sehingga subjek tidak merasa bosan dan tertarik untuk terus mengikuti.

\section{Pengakuan/Acknowledgements}

Ucapan terima kasih disampaikan oleh Tim PKM pada Direktorat Riset dan Pengabdian Masyarakat (DRPM) Universitas Padjadjaran dengan pembiayaan kegiatan

\footnotetext{
${ }^{36}$ Asosiasi Penyelenggara Jasa Internet Indonesia, Laporan survei internet apjii 2019 - 2020, vol. Q2, hal. .

37 Sampurno MBT; Kusumandyoko TC; Islam MA, "Budaya Media Sosial, Edukasi Masyarakat dan Pandemi COVID-1,” SALAM: Jurnal Sosial \& Budaya Syar-I 7, no. 6 (2020): 529-42.
} 
pengabdian masyarakat melalui Hibah Internal Unpad tahun anggaran 2020 Nomor : 1397/UN6.3.1/PM/2020. Ucapan terima kasih juga disampaikan kepada mahasiswa dan narasumber untuk keterlibatan dan partisipasi aktifnya sehingga kegiatan ini bisa terselenggara dengan baik dan berjalan sesuai tujuan yang ditetapkan.

\section{Referensi}

Ambardi, Hermin Indah Wahyuni, Kuskridho, Poppy S. Winanti, dan Wawan Mas'udi. Policy Brief: Problem Infodemic Dalam Merespon Pandemi COVID-19, 2020.

Ariani, Mewa, Achmad Suryana, Sri Hastuti Suhartini, dan Handewi Purwati Saliem. "Keragaan Konsumsi Pangan Hewani Berdasarkan Wilayah dan Pendapatan Di Tingkat Rumah Tangga." Analisis Kebijakan Pertanian 16, no. 2 (2018): 147-163.

Asosiasi Penyelenggara Jasa Internet Indonesia. Laporan survei internet apjii 2019 2020. Vol. Q2, 2020.

Bafadhal, Oemar Madri, dan Anang Dwi Santoso. "Memetakan Pesan Hoaks Berita COVID-19 Di Indonesia Lintas Kategori, Sumber dan Jenis Disinformasi." Bricolage: Jurnal Magister Ilmu Komunikasi 6, no. 2 (2020): 235-249.

Daeli, Widi Astutty Casimira, dan Atik Nurwahyuni. "Determinan Sosial Ekonomi Konsumsi Minuman Berpemanis di Indonesia: Analisis Data Susenas 2017." Jurnal Ekonomi Kesehatan Indonesia 4, no. 1 (2019).

Faizah, Silviana Nur, Ummu Khairiyah, Winarto Eka Wahyudi, dan Mudzaki Risma. "Pendampingan Orang Tua Siswa Melalui Penyusunan Media Alat Hitung Manual ( ALHIMA ) dalam Mendampingi Anak Belajar dari Rumah Selama Masa Pandemi Covid-19." Engagement: Jurnal Pengabdian Kepada Masyarakat 04, no. 02 (2020): $327-342$.

Fakultas Kedokteran Universitas Gadjah Mada. "Konsumen Minuman Berpemanis Tertinggi Ke-3 di Asia Tenggara.” Diakses Januari 20, 2021. https://fk.ugm.ac.id/indonesia-konsumen-minuman-berpemanis-tertinggi-ke-3-diasia-tenggara/Indonesia.

Kementerian Kesehatan RI. “Ayo Bersama Cegah Penularan Virus Corona (COVID-19),” 2020.

_-_. Panduan Gizi Seimbang Pada Masa Pandemi Covid-19, 2020.

___. "Pedoman Pencegahan Dan Pengendalian Coronavirus Disease (COVID-19)" (2020).

Kementerian Pertanian RI. "Kebijakan Pemerintah dalam Mendukung Terwujudnya Kemandirian Protein Hewani." Diakses Februari 1, 2021. https://www.agropustaka.id/presentasi/unduh.

Menteri Kesehatan RI. "Peraturan Menteri Kesehatan Republik Indonesia No. 28 tahun 2019 tentang Angka Kecukupan Gizi Yang dianjurkan Untuk Masyarakat Indonesia," 2019. 
-_- Permenkes No. 14 Tahun 2014 tentang Pedoman Gizi Seimbang, 2014.

Nugraheny, Dian Erika. "Tren Kasus Covid-19 di Kota, Desa, dan Perbandingannya dengan Data Dunia." Last modified 2020. https://nasional.kompas.com/read/2020/08/27/07105681/tren-kasus-covid-19di-kota-desa-dan-perbandingannya-dengan-data-dunia?page=all.

O'Connor L, Imamura F, Brage S, Griffn SJ, Wareham NJ, Forouhi NG. "Intakes and sources of dietary sugars and their association with metabolic and infammatory markers." Clin Nutr 37 (2018): 1313-1322.

Perhimpunan Dokter Spesialis Gizi Klinik Indonesia. Panduan Praktis Penatalaksanaan Nutrisi COVID-19. 1 ed., 2020.

Prabandari YS, Bintoro BS, Yusuf IU. "Pertanyaan dan nasihat dokter untuk konsumsi sayur dan buah:penelitian potong lintang pada 10 puskesmas di Yogyakarta dan Sleman." Jurnal Gizi Klinik Indonesia 10, no. 2 (2013).

Sampurno MBT; Kusumandyoko TC; Islam MA. "Budaya Media Sosial, Edukasi Masyarakat dan Pandemi COVID-1.” SALAM: Jurnal Sosial \& Budaya Syar-I 7, no. 6 (2020): 529-42.

Satuan Tugas Penanganan COVID-19. "Analisis Data COVID-19 Indonesia Update 23 Mei 2021," 2021.

Setyowati, Endah, dan Alviani Permata. "Service Learning: Mengintegrasikan Tujuan Akademik Dan Pendidikan Karakter Peserta Didik Melalui Pengabdian Kepada Masyarakat" 1, no. 2 (2018): 143-152.

Sumarmi, Sri. "Kerja Harmoni Zat Gizi dalam Meningkatkan Imunitas Tubuh Terhadap Covid-19: Mini Review." Amerta Nutr (2020): 250-256.

Wajdi, Muh Barid Nizarudin, M. Burhanuddin Ubaidillah, Sri Mulyani, Khoirul Anwar, Lailatul Istiqomah, Fauziyah Rahmawati, Sholihatul Hikmawati Atik, Diah Retno Ningsih, dan Hasan Syaiful Rizal. "Pendampingan Redesign Pembelajaran Masa Pandemi Covid- 19 bagi Tenaga Pendidik di Lembaga Pendidikan berbasis Pesantren di Jawa Timur." Engagement: Jurnal Pengabdian Kepada Masyarakat 04, no. 01 (2020): 266-277.

Warshaw, H, dan Steven V. Eldeman. "Practical Strategies to Help Reduce Added Sugars Consumption to Support Glycemic and Weight Management Goals." American Diabetes Association 39, no. 1 (2020).

WHO. Policy Brief: COVID-19 in an Urban World, 2020.

World Health Organization. Guideline: Sugars Intake for Adults and Children, 2015.

Zarocostas, John. "How to fight an infodemic." Vol 395. Last modified 2020. www.thelancet.com. 